\title{
Anionic Hapten-Antibody Reactions on Various Cationic Bilayer Membrane Systems
}

\author{
Hirotaka Ihara, Tomoaki Arimura, Takashi Imamura, Eiko SATOH, \\ Toyoki Kunitake, ${ }^{*}$ and Chuichi Hirayama \\ Department of Applied Chemistry, Faculty of Engineering, \\ Kumamoto University, Kumamoto 860, Japan \\ ${ }^{*}$ Department of Organic Synthesis, Faculty of Engineering, \\ Kyushu University, Fukuoka 812, Japan
}

(Received February 10, 1992)

\begin{abstract}
Antigen-antibody reactions using $N^{\alpha}, N^{\varepsilon}$-bis(2,4-dinitrophenyl) L-lysine as an anionic hapten were examined in the presence of various cationic bilayer membranes. The turbidity change of the mixture provided information on the dispersion state of bilayer membranes. The degree of the turbidity change was closely related to the concentration of the haptens and the antibodies. In addition, the agglutination was remarkably dependent on the chemical structure of matrix amphiphiles, and there were two variants of the agglutination mode when the antigen-antibody reaction was examined at $35^{\circ} \mathrm{C}$ : one showed turbidity decrease with the hapten-antibody reaction and the other one did increase. According to DSC studies, the difference is attributable to different physical states resulting from the phase transition of matrix membranes.
\end{abstract}

KEY WORDS Amphiphile / Bilayer Membrane / Agglutination / Hapten / Immunoassay / Phase Transition /

There has been a great interest in the development of a simple, sensitive and rapid immunoassay using liposomes of phospholipids as carrier particles. This technique has two variants. The lysis technique depends on release of an indicator (enzyme, fluorescent dye, etc.) entrapped in vesicles by antigen-antibody reaction on the surface of membranes. ${ }^{1-4}$ The passive agglutination technique uses liposomal vesicles in place of conventional latex. ${ }^{5,6} \mathrm{In}$ our previous report, we described application of totally synthetic bilayer membranes using dihexadecylammonium bromide to immunoassay $^{6}$ and this system showed possibility of applicability to high sensitive and rapid immunoassay in the antigen-antibody reaction for anti DNP-antibodies. ${ }^{6}$ This system has many advantages compared with liposomal vesicles, because we can select physically and chemically stable bilayer membrane systems which possess morphologic and physicochemical properties suitable to our purpose. In addition, cationic property of carrier membranes can be utilized as a driving force to concentrate anionic samples on the membranes, although it may cause non-specific agglutination.

In this study, various cationic bilayer membranes were investigated as carrier particles to immunoassay (the chemical structures of amphiphiles used in this study are given below). It was found that the sensitivity of the immune response was remarkably dependent on the chemical structure of membrane amphiphiles. We also discuss the agglutination mechanism of matrix membranes that is associated with anionic hapten-antibody reaction. 


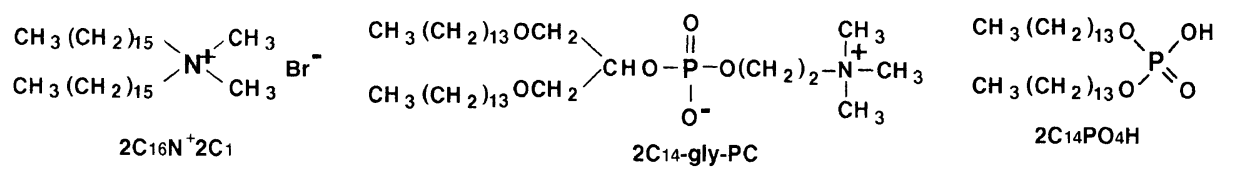

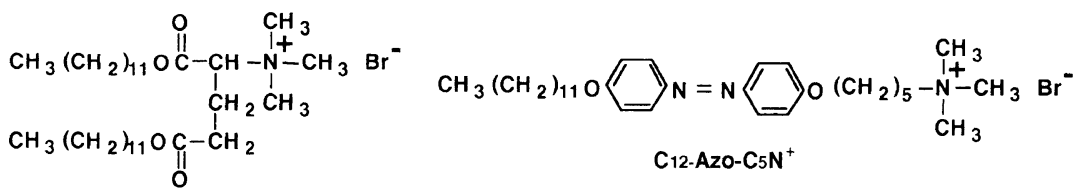

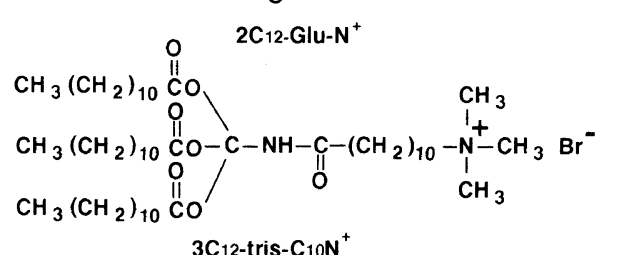

$3 \mathrm{C}_{12}$-tris- $\mathrm{C}_{10 \mathrm{~N}^{+}}$

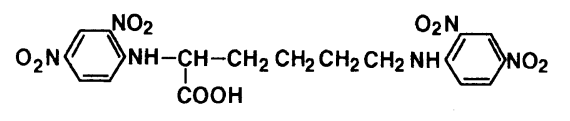

hapten: DNP-Lys(DNP)

\section{EXPERIMENTAL}

\section{Materials}

Dihexadecyldimethylammonium bromide $\left(2 \mathrm{C}_{16} \mathrm{~N}^{+} 2 \mathrm{C}_{1}\right)$ was prepared by stepwise alkylation. $^{7}$

Di(tetradecyl)phosphate $\left(2 \mathrm{C}_{14} \mathrm{PO}_{4} \mathrm{H}\right), 2 \mathrm{C}_{12^{-}}$ GluPhe- $\mathrm{C}_{10} \mathrm{~N}^{+}, 2 \mathrm{C}_{12}$-Glu-N $\mathrm{N}^{+}, 3 \mathrm{C}_{12}$-tris$\mathrm{C}_{10} \mathrm{~N}^{+}, \mathrm{C}_{12}$-Azo- $\mathrm{C}_{5} \mathrm{~N}^{+}$and $2 \mathrm{C}_{14}$-gly-PC were obtained from Sogo Pharmaceutical Co., Ltd. $N^{\alpha}, N^{\varepsilon}$-Bis(2,4-dinitrophenyl)-L-lysine (DNPL) and $N$-(2,4-dinitrophenyl)-glycine (DNPG) were purchased from Tokyo Kasei Kogyo Co., Ltd. (Tokyo, Japan). Rabbit anti-DNP antibodies and $N$-2-hydroxyethylpiperazine- $N^{\prime}-2$ ethanesulfonic acid (HEPES) were purchased from Miles Ltd. (Kankakee, IL, U.S.A.) and Wako Pure Chemical Industries, Ltd. (Osaka, Japan), respectively.

\section{Assay Procedure}

A typical procedure is as follows: the amphiphiles were dispersed in $10 \mathrm{ml}$ of distilled water by sonicating ( $200 \mathrm{~W}, 2 \mathrm{~min})$, using an ultrasonic generator with a $4280 \mathrm{~S}$ type vibrator (Kaijo Denki Co., Ltd.). The clear solution

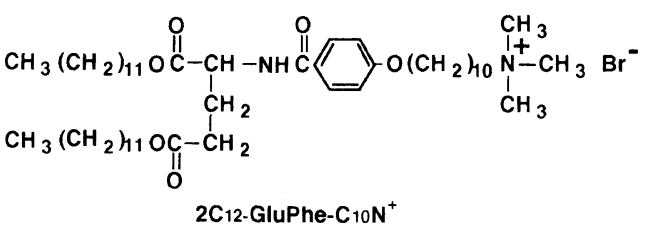

$(1.0 \mathrm{ml})$ was diluted to $100 \mathrm{ml}$ with HEPES buffer ( $\mathrm{pH} 7.2,0.02 \mathrm{M})$. This membrane solution $(0.60 \mathrm{ml})$ and phosphate buffer $(0.10 \mathrm{M}$, $\mathrm{pH}$ 7.2, $6.0 \mu \mathrm{l})$ containing rabbit anti DNPantibodies were mixed in a black quartz cell with a $10 \mathrm{~mm}$ path length and $2 \mathrm{~mm}$ path width, and shaken. After being allowed to stand at $35^{\circ} \mathrm{C}$ for $10 \mathrm{~min}$, a hapten solution ( $7.0 \mu \mathrm{l})$ containing $140 \mathrm{ng}$ of DNPL was added to the membrane solution. The turbidity change due to aggregation of bilayer membranes was spectrophotometrically followed using a JASCO UVIDEC 660. Sensitivity was indicated as $\Delta D_{10}$ in the following equation.

$$
\Delta D_{10}=D_{10}-D_{10, \text { spont }}
$$

where $D_{10}$ and $D_{10 \text {,spont }}$ are the absorbance at $500 \mathrm{~nm}$ after $10 \mathrm{~min}$ in the presence and absence of antibodies, respectively.

\section{Other Measurements}

DSC (differential scanning calorimetry) thermograms of carrier membranes in HEPES buffer solutions were obtained using a heating rate of $2.0^{\circ} \mathrm{C} \mathrm{min}^{-1}$ with Seiko I \& E SSC-580/DSC-10 instruments. 
The aggregation morphology was observed with a JEOL-200FX electron microscope. The sample solutions were prepared in water or HEPES buffer solutions without any other staining agent and a few drop of these solutions were applied to carbon-coated copper grids. After being dried in air at $35^{\circ} \mathrm{C}$, the copper grids were contacted to aqueous solutions containing $2 \mathrm{wt} \%$ of uranyl acetate or ammonium molybdate for a few minute, and then dried in air for $30 \mathrm{~min}$ at $35^{\circ} \mathrm{C}$.

\section{RESULTS AND DISCUSSION}

\section{Courses of Turbidity Change}

Aqueous bilayer membranes showed specific turbidity depending on the amphiphiles. The turbidity estimated by the absorbance increased with lowering the wavelength, because the turbidity was closely related to lightscattering with bilayer aggregates. It was observed that the turbidity in cationic membrane systems changed by addition of anionic haptens, DNPL. The maximum turbidity was observed when cationic $2 \mathrm{C}_{16} \mathrm{~N}^{+} 2 \mathrm{C}_{1}$ and anionic DNPL were mixed in equimolar concentration. Therefore, the increase of turbidity in the cationic membrane systems is caused by electrostatic interaction between the membranes and the haptens.

The turbidity change accompanied with hapten-antibody reaction was spectrophotometrically followed using the absorbance at $500 \mathrm{~nm}$. This wavelength was selected to reduce the contribution of the absorption due to chromophoric groups of DNPL and amphiphiles. Figure 1 shows the time courses of turbidity change in two kinds of cationic membrane systems. It is clear that there are two variants in the mode of the turbidity change: Figure 1a shows that the turbidity of $2 \mathrm{C}_{16} \mathrm{~N}^{+} 2 \mathrm{C}_{1}$ solutions increased with addition of anionic hapten, DNPL, and were suppressed in the presence of anti DNP-antibodies and DNPL. Figure $1 \mathrm{~b}$ shows that the turbidity of $3 \mathrm{C}_{12}$-tris- $\mathrm{C}_{10} \mathrm{~N}^{+}$solutions changed slightly

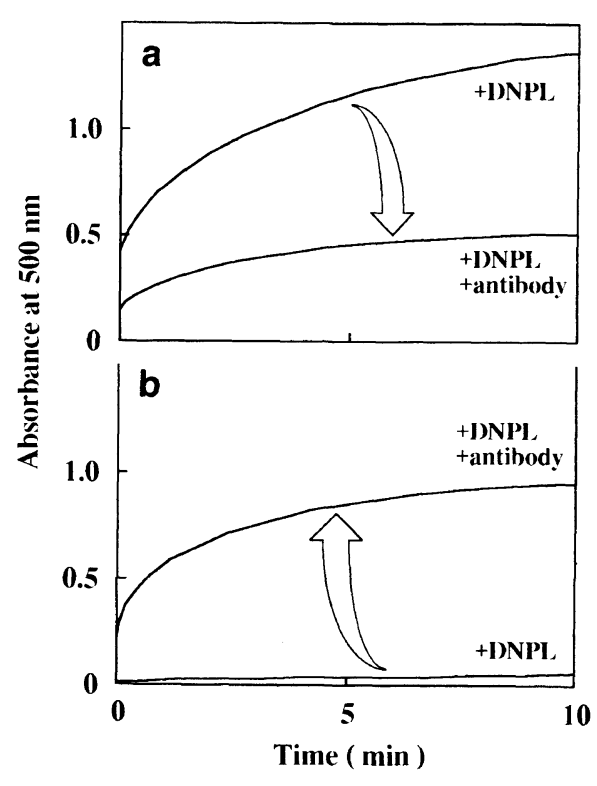

Figure 1. Time courses of turbidity in cationic bilayer membrane systems in the presence of haptens and antibodies. There are two variants, which are classified as suppression and acceleration types, in the mode of the turbidity change. Conditions: amphiphiles, $0.1 \mathrm{mM}$; temp, $35^{\circ} \mathrm{C}$; anti DNP-antibody, $0.14 \mu \mathrm{g} \mathrm{ml}^{-1}$; DNPL, $34 \mu \mathrm{g} \mathrm{ml}^{-1} ; 0.02 \mathrm{~mol} \mathrm{ml}^{-1}$ HEPES buffer ( $\mathrm{pH}$ 7.2). a, $2 \mathrm{C}_{16} \mathrm{~N}^{+} 2 \mathrm{C}_{1} ;$ b, $3 \mathrm{C}_{12}$-tris- $\mathrm{C}_{10} \mathrm{~N}^{+}$.

with addition of DNPL, but increased in the presence of anti DNP-antibodies and DNPL. These two variants are classified as suppression and acceleration types in this article.

Figure 2 shows the concentration dependency $\Delta D_{10}$ as a sensitivity measure was of immune reactivity. The value of $\Delta D_{10}$ which is estimated by eq 1 stands for the degree of turbidity change after $10 \mathrm{~min}$. According to Figure 2, the sensitivity is remarkably dependent on the amphiphile. $2 \mathrm{C}_{12}-\mathrm{Glu}-\mathrm{N}^{+}$as well as $2 \mathrm{C}_{16} \mathrm{~N}^{+} 2 \mathrm{C}_{1}$ belonged to the suppression type, whereas $2 \mathrm{C}_{12}$-GluPhe- $\mathrm{C}_{10} \mathrm{~N}^{+}$and $\mathrm{C}_{12^{-}}$ Azo- $\mathrm{C}_{5} \mathrm{~N}^{+}$showed acceleration type behavior similar to that of $3 \mathrm{C}_{12}$-tris- $\mathrm{C}_{10} \mathrm{~N}^{+}$(in the case of the measurement at $35^{\circ} \mathrm{C}$ ).

\section{Effect of Ionic Head-Groups of Matrix Am- phiphiles}

It is known that $2 \mathrm{C}_{14} \mathrm{PO}_{4} \mathrm{H}$ and $2 \mathrm{C}_{14}$-gly- 


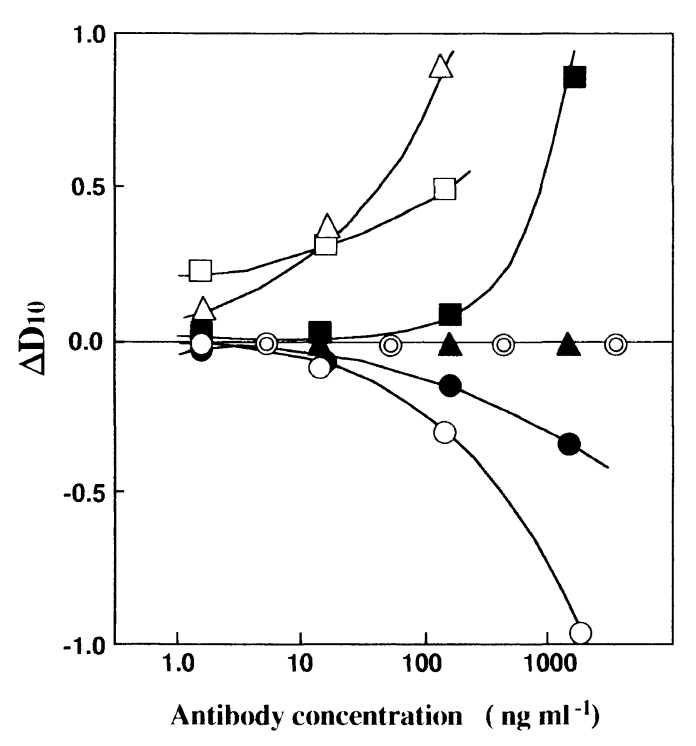

Figure 2. Anti-DNP antibody detection using various bilayer membranes. The sensitivity $\left(\Delta D_{10}\right)$ is remarkably dependent on the amphiphile. $2 \mathrm{C}_{12}-\mathrm{Glu}-\mathrm{N}^{+}$and $2 \mathrm{C}_{16} \mathrm{~N}^{+} 2 \mathrm{C}_{1}$ belong to the suppression type, whereas $3 \mathrm{C}_{12}$-tris- $\mathrm{C}_{10} \mathrm{~N}^{+}, \quad 2 \mathrm{C}_{12}$-GluPhe- $\mathrm{C}_{10} \mathrm{~N}^{+}$and $\mathrm{C}_{12}$-Azo$\mathrm{C}_{5} \mathrm{~N}^{+}$show the acceleration type. $\mathrm{O}, 2 \mathrm{C}_{16} \mathrm{~N}^{+} 2 \mathrm{C}_{1}$; ○, $2 \mathrm{C}_{12} \mathrm{GluN}^{+} ; \square, 2 \mathrm{C}_{12} \mathrm{PhC}_{10} \mathrm{~N}^{+} ; \mathbf{\square}, \mathrm{C}_{12} \mathrm{AzoC}_{5} \mathrm{~N}^{+}$; $\triangle, 3 \mathrm{C}_{12}$-tris- $\mathrm{C}_{10} \mathrm{~N}^{+} ; \boldsymbol{\Delta}, 2 \mathrm{C}_{14}$-gly-PC; $\odot, 2 \mathrm{C}_{14} \mathrm{PO}_{4} \mathrm{H}$. Conditions: amphiphiles, $0.1 \mathrm{mM}$; temp, $35^{\circ} \mathrm{C}$; $\mathrm{DNPL}$, $34 \mu \mathrm{g} \mathrm{ml}^{-1} ; 0.02 \mathrm{M}$ HEPES buffer (pH 7.2).

PC can form anionic and zwitter ionic bilayer membranes in aqueous solutions. ${ }^{8}$ No turbidity change due to hapten-antibody reaction was detected in the presence of either an anionic $2 \mathrm{C}_{14} \mathrm{PO}_{4} \mathrm{H}$ and a zwitterionic $2 \mathrm{C}_{14}$ gly-PC at temperature range of $30-70^{\circ} \mathrm{C}$ (Figure 2). The UV spectra showed no significant spectral change of DNPL $(355 \mathrm{~nm})$ in the presence of $2 \mathrm{C}_{14} \mathrm{PO}_{4} \mathrm{H}$ and $2 \mathrm{C}_{14}$-gly- $\mathrm{PC}$ lipid bilayers, although slight $\lambda_{\max }$ shift to $353 \mathrm{~nm}$ with decrease of the absorbance at 370 $420 \mathrm{~nm}$ was observed in cationic $2 \mathrm{C}_{16} \mathrm{~N}^{+} 2 \mathrm{C}_{1}$ membrane systems. This indicates that DNPL does not interact with $2 \mathrm{C}_{14} \mathrm{PO}_{4} \mathrm{H}$ and $2 \mathrm{C}_{14}$ gly-PC, and that cationic property of carrier membranes is essential for the turbidity change.
Aggregation Morphology of Carrier Particles

It is known that the amphiphiles used in this study can form bilayer membrane aggregates and the morphology is remarkably dependent on the chemical structure of amphiphiles. ${ }^{9}$ The aggregation form in a HEPES solution was observed by electron microscopy with a negative staining method and the morphology was classified according to previous articles by Kunitake. ${ }^{9}$ The staining procedure was carried out after drying the sample solution in order to reduce perturbation of the staining agent. The vesicle form was recognized as a globular form. As summarized in Table I, the aggregation forms determined in this study agreed almost completely with the morphology reported previously. ${ }^{9}$ According to Table I, it seems that the agglutination mode in the hapten-antibody reaction is independent of the morphology of cationic carrier membranes.

\section{Phase Transition of Carrier Membranes}

Table I summarizes the value of $T_{\mathrm{C}}$ for other carrier membranes. All the values were determined in the same buffer solution as used for the measurement of immune reactivity. As is evident from Table $\mathrm{I}$, the aqueous aggregates from $2 \mathrm{C}_{12}-\mathrm{Glu}-\mathrm{N}^{+}$and $2 \mathrm{C}_{16} \mathrm{~N}^{+} 2 \mathrm{C}_{1}$ (suppression types) have lower $T_{\mathrm{C}}$ than the measurement temperature $\left(35^{\circ} \mathrm{C}\right)$ : both aggregates are in liquid crystalline states at $35^{\circ} \mathrm{C}$. On the contrary, the other cationic membranes (acceleration types) have higher $T_{\mathrm{C}}$ : the aggregates are in gel states. This indicates that the mode of agglutination is closely related to the physical states of carrier membranes. As supported this estimation, we reported briefly that sensitivity of immune reactivity was influenced by temperature, and the $2 \mathrm{C}_{16} \mathrm{~N}^{+} 2 \mathrm{C}_{1}$ system provided an inflection point near $28^{\circ} \mathrm{C}$ in the plots of temperature vs. $\Delta D_{10}$ (Figure 3 ). This inflection point agrees with the endothermic peak (peak top, $T_{\mathrm{C}}$ ) of the aqueous aggregate determined by DSC measurement. Figure 3 shows that the mode of agglutination changes from "suppression" to "acceleration" when 
Immune Reaction on Cationic Bilayer Membranes

Table I. Agglutination mode of various bilayer membranes

\begin{tabular}{|c|c|c|c|c|c|}
\hline \multirow{2}{*}{ Membranes $^{\mathrm{a}}$} & \multirow{2}{*}{$\begin{array}{l}\text { Charge of } \\
\text { lipid }\end{array}$} & \multirow{2}{*}{$\begin{array}{c}\text { Agglutination mode } \\
\text { at } 35^{\circ} \mathrm{C}\end{array}$} & \multirow{2}{*}{$\frac{T_{\mathrm{C}}^{\mathrm{c}}}{{ }^{\circ} \mathrm{C}}$} & \multicolumn{2}{|c|}{ Morphology } \\
\hline & & & & Buffer $^{d}$ & Water \\
\hline $2 \mathrm{C}_{12}-\mathrm{Glu}-\mathrm{N}^{+}$ & Cationic & Suppression & 27 & Globules & Vesicles $^{\mathrm{f}}$ \\
\hline $\begin{array}{l}2 \mathrm{C}_{16} \mathrm{~N}^{+} 2 \mathrm{C}_{1} \\
\left(2 \mathrm{C}_{16} \mathrm{~N}^{+} 2 \mathrm{C}_{1}\right)^{\mathrm{e}}\end{array}$ & Cationic & $\begin{array}{l}\text { Suppression } \\
(\text { Acceleration })^{\mathrm{e}}\end{array}$ & 28 & Globules & Vesicles ${ }^{\mathrm{g}}$ \\
\hline $3 \mathrm{C}_{12}$-tris- $\mathrm{C}_{10} \mathrm{~N}^{+}$ & Cationic & Acceleration & 39 & Globules & Tubules $^{\mathrm{h}}$ \\
\hline $2 \mathrm{C}_{12}$ GluPhe- $\mathrm{C}_{10} \mathrm{~N}^{+}$ & Cationic & Acceleration & 46 & Tubules & Rods $^{i}$ \\
\hline $\mathrm{C}_{12}-\mathrm{Azo}-\mathrm{C}_{5} \mathrm{~N}^{+}$ & Cationic & Acceleration & 76 & Disks & Globules $^{\mathrm{j}}$ \\
\hline $2 \mathrm{C}_{14}$-gly-PC & Zwitterionic & No response & 37 & Globules & - \\
\hline $2 \mathrm{C}_{14} \mathrm{PO}_{4} \mathrm{H}$ & Anionic & No response & 62 & Globules & Vesicles $^{\mathbf{k}}$ \\
\hline
\end{tabular}

a Membrane, $0.1 \mathrm{mM}$.

b DNPL, $34 \mu \mathrm{g} \mathrm{ml}^{-1}$; anti DNP-antibody, $0.14 \mu \mathrm{g} \mathrm{ml}^{-1}$.

c Gel-to-liquid crystalline phase transition temperature.

d $0.02 \mathrm{M}$ HEPES buffer ( $\mathrm{pH} 7.2$ ).

e Mesurement temperature, $15^{\circ} \mathrm{C}$.

${ }^{\mathrm{f}} \operatorname{Ref} 12 .{ }^{\mathrm{g}} \operatorname{Ref} 13 .{ }^{\mathrm{h}} \operatorname{Ref} 14{ }^{\mathrm{i}} \operatorname{Ref} 15,{ }^{\mathrm{j}} \operatorname{Ref} 16 .{ }^{\mathrm{k}} \operatorname{Ref} 17$.

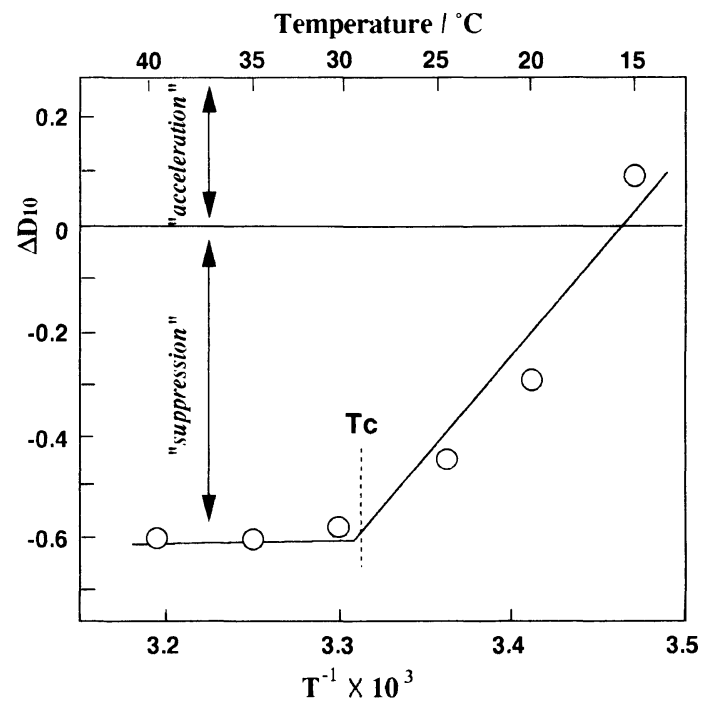

Figure 3. Temperature dependence of sensitivity $\left(\Delta D_{10}\right)$. Conditions: $2 \mathrm{C}_{16} \mathrm{~N}^{+} 2 \mathrm{C}_{1}, 0.1 \mathrm{mM} ; \mathrm{DNPL}, 34 \mu \mathrm{g} \mathrm{ml}^{-1}$; anti DNP-antibody, $140 \mathrm{ng} \mathrm{ml}^{-1} ; 0.02 \mathrm{M}$ HEPES buffer (pH 7.2).

the measurement temperature alters from $40^{\circ} \mathrm{C}$ to $15^{\circ} \mathrm{C}$.

\section{Mechanisms of Immune Reactivity}

A turbidity change was observed only in cationic membrane systems. This indicates that an ionic interaction is an important factor

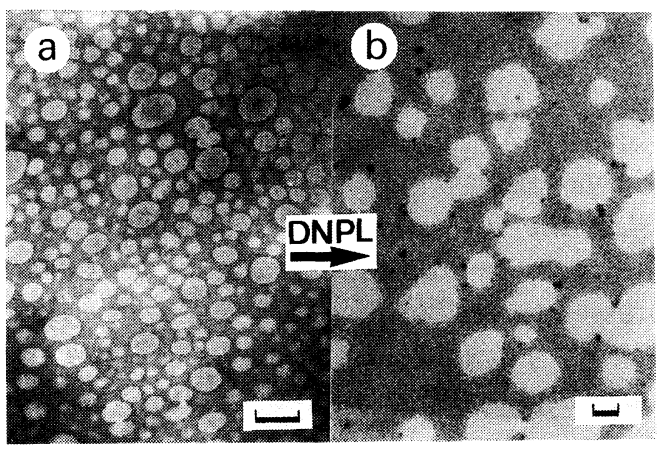

Figure 4. Electron micrographs of $2 \mathrm{C}_{16} \mathrm{~N}^{+} 2 \mathrm{C}_{1}$ alone (a) and $2 \mathrm{C}_{16} \mathrm{~N}^{+} 2 \mathrm{C}_{1}$ containing DNPL (b). Addition of DNPL to the solution induces membrane fusions to cause the formation of larger aggregates. Conditions: $2 \mathrm{C}_{16} \mathrm{~N}^{+} 2 \mathrm{C}_{1}$ and DNPL, $0.1 \mathrm{mM}$; temp, $35^{\circ} \mathrm{C} ; 0.02 \mathrm{M}$ HEPES buffer (pH 7.2); scale bars, $1000 \AA$.

for immune reactivity. According to our previous study, ${ }^{6}$ a light scattering measurement indicated that increase of turbidity in the cationic membranes from $2 \mathrm{C}_{16} \mathrm{~N}^{+} 2 \mathrm{C}_{1}$ with anionic hapten, DNPL included morphological transitions of matrix membranes to larger aggregates. In the present study, the transition was detected by electron microscopy. Figure $4 \mathrm{a}$ showed that $2 \mathrm{C}_{16} \mathrm{~N}^{+} 2 \mathrm{C}_{1}$ was dispersed in a HEPES buffer solution as globular aggregates (vesicles) with diameter 

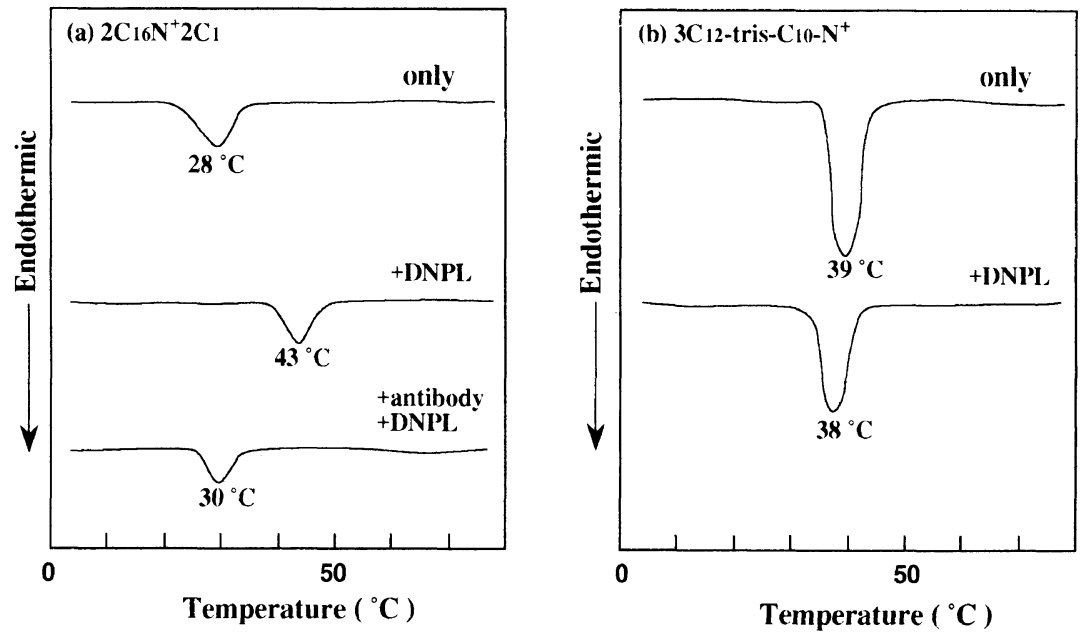

Figure 5. DSC thermograms of membrane solutions. The transitions (Figure 5a) indicate that the addition of DNPL and anti DNP-antibodies induce the change of the ordered structures of the $2 \mathrm{C}_{16} \mathrm{~N}^{+} 2 \mathrm{C}_{1}$ membranes. On the contrary, DNPL by itself provides only small perturbation to the ordered structures of the $3 \mathrm{C}_{12}$-tris- $\mathrm{C}_{10} \mathrm{~N}^{+}$membranes (Figure 5b). Conditions: amphiphiles, $0.01 \mathrm{M}$; molar ratio, amphiphiles: $\mathrm{DNPL}=1: 1$; heating rate, $2.0^{\circ} \mathrm{C} \mathrm{min}^{-1} ; 0.02 \mathrm{M} \mathrm{HEPES}$ buffer $(\mathrm{pH} 7.2)$.

$150-600 \AA$. Furthermore, addition of DNPL to this solution induced membrane fusions to cause the formation of larger aggregates as shown in Figure 4b. No similar fusion was observed in either $3 \mathrm{C}_{12}$-tris- $\mathrm{C}_{10} \mathrm{~N}^{+}$(acceleration type) membrane systems or in $2 \mathrm{C}_{14} \mathrm{PO}_{4} \mathrm{H}$ and $2 \mathrm{C}_{14}$-gly-PC membrane systems. In order to understand this difference, calorimetric behaviors of matrix membranes were examined in the systems containing DNPL and anti DNP-antibodies. Figure 5a shows DSC thermograms in the $2 \mathrm{C}_{16} \mathrm{~N}^{+} 2 \mathrm{C}_{1}$ systems. The aqueous solution containing $2 \mathrm{C}_{16} \mathrm{~N}^{+} 2 \mathrm{C}_{1}$ alone had a single endothermic transition $\left(T_{\mathrm{C}}\right.$, $28^{\circ} \mathrm{C}$ ). This transition due to a gel-to-liquid crystalline transition. When DNPL was added to the $2 \mathrm{C}_{16} \mathrm{~N}^{+} 2 \mathrm{C}_{1}$ solution, the peak-top temperature shifted to $43^{\circ} \mathrm{C}$. The subsequent addition of anti DNP-antibodies to this solution lowered the peak-top temperature from 43 to $30^{\circ} \mathrm{C}$. These transitions indicate that the addition of DNPL and anti DNP-antibodies induce the change of the ordered structures of $2 \mathrm{C}_{16} \mathrm{~N}^{+} 2 \mathrm{C}_{1}$ membranes. On the other hand, without addition of DNPL the $3 \mathrm{C}_{12}$-tris-
$\mathrm{C}_{10} \mathrm{~N}^{+}$membranes showed a higher phase transition temperature $\left(T_{\mathrm{C}}, 39^{\circ} \mathrm{C}\right)$ (Figure $\left.5 \mathrm{~b}\right)$. Interestingly, addition of DNPL to the solution induced only a slight shift of $T_{\mathrm{C}}$ from 39 to $38^{\circ} \mathrm{C}$. This indicates that DNPL by itself provides only small perturbation to the ordered structures of $3 \mathrm{C}_{12}$-tris- $\mathrm{C}_{10} \mathrm{~N}^{+}$.

On the basis of these results, a course of turbidity changes in the suppression type membrane systems is proposed as shown in Figure 6a: $2 \mathrm{C}_{16} \mathrm{~N}^{+} 2 \mathrm{C}_{1}$ membranes as a typical example lie in liquid crystalline states at $35^{\circ} \mathrm{C}$. DNPL anionic haptens act as counter ions and the electrostatic binding on the $2 \mathrm{C}_{16} \mathrm{~N}^{+} 2 \mathrm{C}_{1}$ membranes induces morphological transition including the transition of physical states from liquid crystal to gel. On the other hand, ati DNP-antibodies suppress the electrostatic interaction of DNPL to the matrix membranes because of preference of hapten-antibodies reactions. In this case, hapten-anti DNP-antibody reaction does not promote the agglutination of $2 \mathrm{C}_{16} \mathrm{~N}^{+} 2 \mathrm{C}_{1}$ membranes at $35^{\circ} \mathrm{C}$. This indicates that it is too fluid to induce crosslinking of carrier 
a)
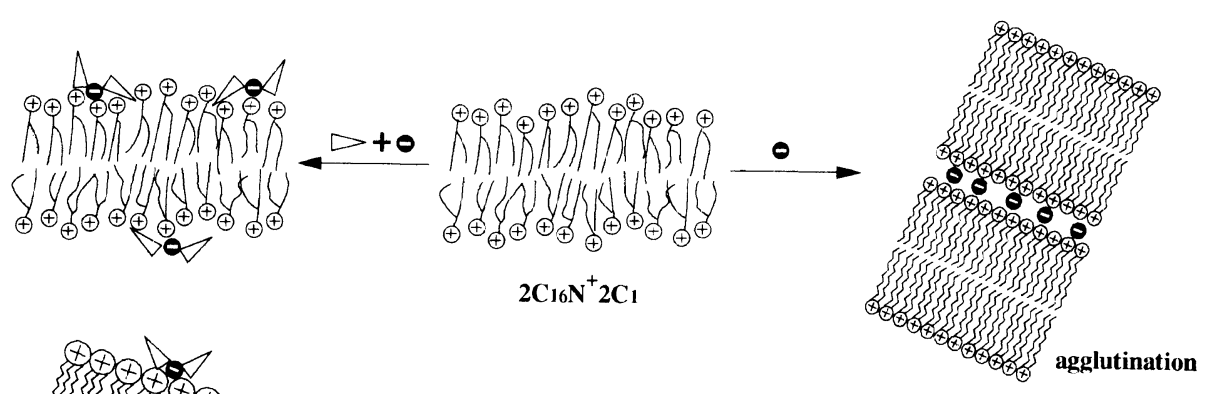

b)
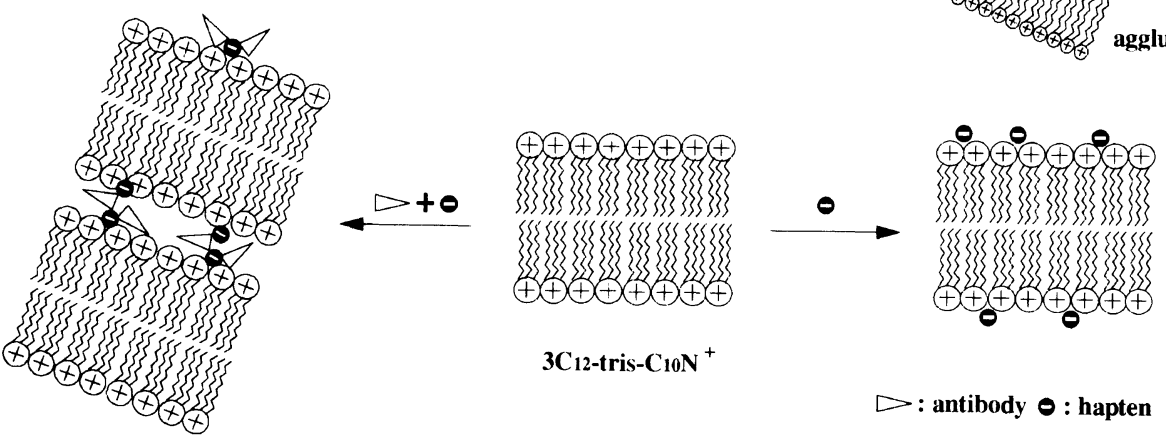

$3 \mathrm{C}_{12-\text { tris-C } 10 \mathrm{~N}^{+}}$

$\triangleright:$ antibody $\odot:$ hapten

agglutination

Figure 6. Schematic representation of agglutination at $35^{\circ} \mathrm{C} .2 \mathrm{C}_{16} \mathrm{~N}^{+} 2 \mathrm{C}_{1}$ membranes as a typical example lie in liquid crystalline states at $35^{\circ} \mathrm{C}$. DNPL anionic haptens act as counter ions and the electrostatic binding on the $2 \mathrm{C}_{16} \mathrm{~N}^{+} 2 \mathrm{C}_{1}$ membranes induces morphological transition including the transition of physical states from liquid crystal to gel. On the other hand, anti DNP-antibodies suppress the electrostatic interaction of DNPL to the matrix membranes because of preference of haptenantibodies reactions. $3 \mathrm{C}_{12}$-tris- $\mathrm{C}_{10} \mathrm{~N}^{+}$membranes as a typical example lie in gel states at $35^{\circ} \mathrm{C}$. Addition of DNPL induces no significant changes on the morphology and physical state of the membranes. Increase of turbidity change occurs both in the presence of DNPL and anti-DNP antibodies.

membranes because $2 \mathrm{C}_{16} \mathrm{~N}^{+} 2 \mathrm{C}_{1}$ membranes lie in the liquid crystal state.

A second course is proposed for the acceleration type (Figure 6b). $3 \mathrm{C}_{12}$-tris- $\mathrm{C}_{10} \mathrm{~N}^{+}$ membranes as a typical example lie in gel states at $35^{\circ} \mathrm{C}$. Addition of DNPL induces no significant changes on the morphology and physical state of the membranes. The difference between this and the $2 \mathrm{C}_{16} \mathrm{~N}^{+} 2 \mathrm{C}_{1}$ membrane system is attributable to the difference in membrane stability based on the physical state. Increase of turbidity change, that is formation of larger aggregates, occurs both in the presence of DNPL and anti DNP-antibodies. This agglutination mechanism is very similar to that of agglutination using conventional polystyrene latex beads. ${ }^{10}$ Presumably, DNPL are concentrated on the

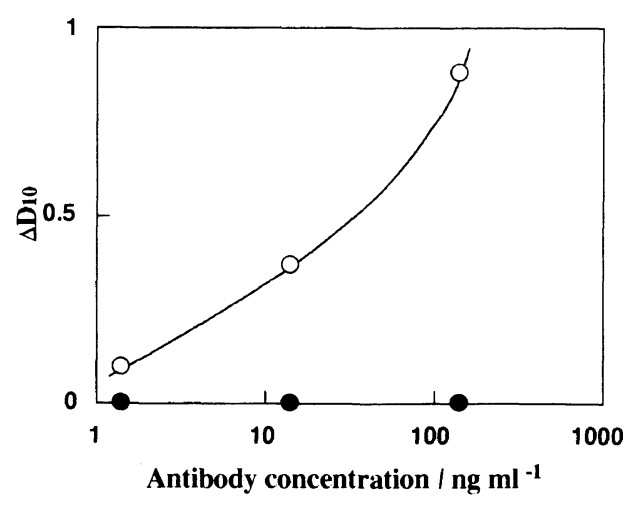

Figure 7. Comparison of turbidity change between DNPL and DNPG in $3 \mathrm{C}_{12}$-tris- $\mathrm{C}_{10} \mathrm{~N}^{+}$membrane systems. Conditions: $3 \mathrm{C}_{12}$-tris- $\mathrm{C}_{10} \mathrm{~N}^{+}, 0.1 \mathrm{mM}$; temp, $35^{\circ} \mathrm{C}$; haptens $(\mathrm{O}$, DNPL;, $\mathrm{DNPG}), 7.1 \times 10^{-5} \mathrm{M}$; HEPES buffer ( $\mathrm{pH}$ 7.2). 
membranes by the electrostatic force and the anti DNP-antibodies are combined to the membranes through the hapten-anti DNPantibody reaction. In addition, the haptenantibody reaction promotes crosslinking of carrier membranes. As supported this assumption, no increase of turbidity were observed when mono DNP-subsituted hapten $(N-(2,4$ dinitrophenyl)-glycine, DNPG) was added in the mixture of $3 \mathrm{C}_{12}$-tris- $\mathrm{C}_{10} \mathrm{~N}^{+}$and anti DNP-antibodies instead of DNPL (Figure 7). This indicates that the agglutination of the membranes is induced through bifunctional haptens.

\section{CONCLUSIONS}

In the present study, various cationic bilayer membranes were examined for detection of immune reactivity. The hapten-antibody reaction is varied as a function of turbidity change accompanying the dispersion states of matrix membranes, and two variants (suppression and acceleration types) in the agglutination mode was appearantly observed. The difference between the two variants is closely related to that of the physical states of the matrix membranes at the measurement temperature. This is consistent with the observation that the $2 \mathrm{C}_{16} \mathrm{~N}^{+} 2 \mathrm{C}_{1}$ membrane systems provided an inflection point at around $28^{\circ} \mathrm{C}$ (corresponding to $T_{\mathrm{C}}$ ) in the plots of the temperature vs. $\Delta D_{10}{ }^{6}$ and that the agglutination mode changed from the suppression to the acceleration type. Similar inflection points have been often observed for biomembrane systems. ${ }^{11}$ Therefore, investigation of immune reactivity on these synthetic, simple bilayer membrane systems is not only important for development of new immunoassay, but also for understanding antigen-antibody reactions on biomembranes.

Acknowledgement. This study was supported in part by a Grant-in-Aid for Scientific Research from the Sagawa Science Foundation.

\section{REFERENCES}

1. R. Wei, C. R. Alving, R. L. Richards, and E. S. Copeland, J. Immunol. Methods, 9, 165 (1975).

2. R. J. Y. Ho and L. Huang, J. Immunol., 134, 4035 (1985).

3. M. Umeda, Y. Ishimori, K. Yoshikawa, M. Takada, and T. Yasuda, J. Immunol. Methods, 95, 15 (1986).

4. D. W. Bowden, M. Rising, G. Aktos, A. Myles, and R. J. Broeze, Clin. Chem., 32, 205 (1986).

5. H. Matsumura, M. Aizawa, H. Yokoyama, and H. Kamei, Chem. Lett., 205 (1987).

6. H. Ihara, T. Imamura, T. Kunitake, and C. Hirayama, Clin. Chim. Acta, 175, 51 (1988).

7. Y. Okahata, H. Ihara, and T. Kunitake, Bull. Chem. Soc. Jpn., 54, 2072 (1981).

8. Y. Okahata, R. Ando, and T. Kunitake, Ber. Bunsenges. Phys. Chem., 85, 789 (1981).

9. T. Kunitake, Y. Okahata, M. Shimomura, S. Yasunami, and T. Takarabe, J. Am. Chem. Soc., 103, 5401 (1981).

10. E. Araki, Bunseki, 9, 605 (1987).

11. For example, E. J. McMurchie, and J. K. Raison, Biochem. Biophys. Acta, 554, 364 (1979).

12. T. Kunitake, N. Nakashima, S. Hayashida, and K. Yonemori, Chem. Lett., 1413 (1979).

13. T. Kunitake and Y. Okahata, J. Am. Chem. Soc., 99, 3860 (1977).

14. T. Kunitake, Seibutsu Butsuri, 21, 1 (1981).

15. T. Akao, T. Osaki, J. Mitoma, A. Ito, and T. Kunitake, Chem. Lett., 311 (1991).

16. T. Kunitake, N. Nakashima, M. Shimomura, Y. Okahata, K. Kano, and T. Ogawa, J. Am. Chem. Soc., 102, 6642 (1980).

17. T. Kunitake, J. Macromol. Sci.-Chem., A13, 587 (1979). 